\title{
The Development of Buddhist Situational Leadership of Administrators in Phrapariyattidhamma Dhamma Division in Sangha Administration Region
} 14

\author{
Phrakru Sujittanan Hitajitto (Tinphowong) ${ }^{1}$, Sin Ngamprakhon $^{2}$, Kasem Sangnont ${ }^{3}$, Teeraphong \\ Somkhaoyai $^{4}$ \\ ${ }^{1,2,3}$ Faculty of Education, Mahachulalongkornrajavidyalaya University, Thailand \\ ${ }^{4}$ Nakhon Si Thammarat Campus, Mahachulalongkornrajavidyalaya University, Thailand \\ sin.ngm@mcu.ac.th, ${ }^{1}$ chaibie2529@
}

\begin{abstract}
The objectives of this research are 1) to study the leadership conditions according to the situation of the administrators of the Dharma School in the Sangha Administration Region 14; Leader according to the Buddhist situation of the executive using a combined research methodology, namely, quantitative research using a sample of 306 persons, and qualitative methods by interviewing 10 experts and focus group of 10 experts. The results research found that: The state of leadership according to the situation of the administrators of the Phrapariyattidhamma School. The executives have opinions at a high level, in descending order, that the executives had the vision to modify the corporate management strategy, friendship, promote morale and morale in performance, leadership development according to the Buddhist situation of the executives with the leadership characteristics according to the four situations: 1) the aspect of change 2) creativity 3) relationship in the organization 4) leadership power and 4 activities for leadership development according to the situation to propose the development of leadership based on the Buddhist situation of the administrators of the Dharma School in the Sangha administration Region 14, consisting of 4 situational leadership characteristics, integration with the Four Sangkhahavatthu. There are 4 activities including 1) 5 Q activities, 2) 5 prompting questions activities, 3) Person management and administration activities, and 4) Power activities.
\end{abstract}

Index Terms

Development of Buddhist, Situational Leadership, Sangha Administration

Article Received: 10 August 2020, Revised: 25 October 2020, Accepted: 18 November 2020

\section{Introduction}

The study of Buddhism of Thai monks from ancient times has come to be popular and is called a principle of DhammaVinai, which is known as the study of Dhamma, which is difficult be studied by for ordinary monks and novices. Therefore, it appears that a small number of monks and novices have understood thorough knowledge of the dhamma and are causing the diocese to lack of competent monks to promote religious affairs, both in education, government and teaching people so Somdej phramahasamanachaokromphrayavachirayanwaroros

(Prince Vachirayanvaroros). therefore, has developed the method for easier learning the Dhamma in Thai language for teaching monks and novices at Wat Bowon Niwet Viharn for the first time since he took the duty of ruling Wat Bowon Niwet Viharn in 1892 B.E. cte, in teaching course for monks and novices to learn Buddhism both the principles of Buddhism and the history of the discipline, as well as to learn to edit Dhamma topics. When he saw that teaching and learning of Dhamma in Thai language, later, has resulted in a more extensive knowledge of the monks and novices. Because it is not difficult to learn as before, His highness intended to extend this approach to the general monks and novices

as well.Somdejphramahasamanachaokromphrayavachirayanwa roros (Prince Vachirayanvaroros).has established a curriculum for the novice to know Dhamma. "Dhamma" for the monks and novices for training and development in the present. [1]
Therefore, in order to meet a better management of the teaching and learning of the Dhamma subject it requires to provide a systematic education in administration and management of education to achieve the goals of education which relies on the professionalism of the school administrators to wide have broad vision, capable morality and ethics, and possesses, both intellectual, emotional and moral intelligence Including professional practice School administrators, therefore, it will lead to educational achievement. [2] It can be said that educational institutions of all levels and types have the main mission of developing learners to have the quality expected according to the level and type of education. The expected quality refers to desirable qualities that will be achieved to learners, including knowledge, understanding, thinking, skills, competence, physical and mental health, and personality traits, values, moral and ethics expected by defining in the expected course, expected by the community and society, expected by the school itself and expected by the learner as well [3]

In case of study the background and importance of the problem, the researcher was therefore is interested in studying the leadership by the Buddhist situation of the administrators of Phrapariyatidhamma school on Sanamluang Division in the Sangha Administration Area, Region 14, to be as a guideline for the development of the leadership of the administrators with stability and continuous growth and able to solve various problems. In the administration of the Buddhist Dhamma School in Dhamma Division for the Sangha Administration, including 
the development of learning the Dhamma School to continue to prosperity.

\section{Research Objectives}

1. To study the state of leadership according to the situation of the administrators of the Phra Pariyatidhamma School in Sanam Luang Division of the Sangha Administration Region 14.

2. To develop leadership based on the Buddhist situation of the administrators of the Phra Pariyatidhamma School.

3. To propose the leadership development according to the Buddhist situation of the administrators of the Phra Pariyatidhamma School.

\section{Research Methods}

Step 1: To study the situation of leadership status of the administrators of the Dhamma School of Dhamma Division in the Sangha Administration, there are 3 steps: 1) Study documents on leadership according to the situation of the administrators,.Data Sources: PhraTripitaka, Books, Textbooks, Research Articles, Website Tools: Study tools, Documents Analysis: By Content Analysis ,2 ). The questionnaire has been distributed on the management status of the management by the questionnaire [3] from the entire population by using random sampling. With the opening of the tables, 306 samples have been obtained and 3) interviewed on leadership conditions.

Step 2 : to develop the leadership according to the Buddhist situation of the administrator. There are 2 steps: Dhamma Department from objectives and 2) to develop by discussion groups by qualified persons / scholars / administrators of the Dhamma Learning Center, Dhamma, with group of 10 people.

Step 3 : to propose the leadership development according to the Buddhist situation of the administrators.. There are 2 steps: revision, correction and presenting with an advisor / advisor with tools: a study document Data analysis: content analysis results: Situational leadership development has been achieved by the administrators.

\section{Research findings.}

The research findings can be discussed as follows:

1. The results of the study, the format of the activities to reduce the study time, increase the learning time of the students at the basic education level according to the government policy, found that the opinions of all four aspects of students were at a high level, namely

Part 1: Learning management, there is a high level of overall practice, i.e. students learn to coexist, considerate and help each other. Students learn and practice happiland develop their own abilities.

Part 2: Enhancing competencies and learning, there is a high level of overall practice, including activity patterns that meet the needs of students. The media / materials used for the activity are appropriate. The duration of the activity is appropriate.

Part3: Strengthen characters and values, there was a high level of overall practice, including activities to cultivate students to become more patriotic, religious and monarchical. The students enjoyed the activities and organizing activities is essential to the daily life of the students.

Part 4: Enhance working, living and life skills, the overall practice level was at a high level, including interest response activities, aptitude, student life promotion activities, activities meet the needs of learners according to their differences, and corresponding to the research results, the format of activities to reduce the study time, increase the knowledge time of the students at the basic education level according to government policy.

In line with Ket Amon's Mingkhaowhas' study of "Conditions and problems according to the policy to reduce school hours Under the Office of Ubon Ratchathani Primary Educational Service Area 4", the research found that the condition and problem of implementation of the policy to reduce school hours in overall practice was at a high level. [6]

And in line with PornthipTaosuwan's research in "Evaluation of the teaching and learning process of primary school teachers: a case study of primary school teachers in Yala Province", the research results were found that ${ }^{4}$ factors related to the teaching and learning process the evaluation side informs the students about the evaluation criteria and has prepared the teaching, review and understand the content before the exam. There is a continuous connection of teaching and teaching materials. [7]

\section{To develop activities to reduce learning time and increase learning time of primary school students.}

Section 1: Learning management includes thoughtful students and helping each other to learn happily, practice and develop, increase one's abilities. Integration to complete $4 \mathrm{Hs}$, namely Head, Heart, Hand, and Health, and the learning time reduction activities of the Office of the Basic Education Commission set out 4 sections, 16 groups. The four sections include 1) learner development activities, 2) building activities, enhance competence and learning, 3) Strengthen characters and values, and 4) Strengthen working skills, livelihoods and life skills.

Section 2: Enhance competency and learning, i.e. activities that respond to student needs. The media / materials used for the activity are appropriate. The duration of the activity is appropriate. The school focuses on organizing activities to enhance competencies in 5 areas, including communication, thinking development, problem solving, use of technology, and life skills development.

Section 3: To strengthen the characters and values, it includes activities to instill students to become more patriotic, religious and monarchical, and to have fun in doing activities. Organizing activities are essential to the daily life of the students, cultivate consciousness and values to benefit society, have a public mind and use of various services, both for the benefit of ourselves and the public, cultivate patriotism, religion, and the monarchy, and cultivate morality, ethics, and good conduct towards 
students with 12 values strengthening characteristics and values Strengthening.

Section 4: Strengthening work skills, livelihoods, and life skills, including interest-response activities, aptitude, student life promotion. Activities meet the needs of learners according to their differences, integrate learning experiences with lifestyle, life skills, work with others, love and unity of working in a group, and building work skills. For the lifestyle that the executives and teachers must organize activities that students can use in their daily life, each activity has to be repeated and always focused on review so that students do not forget the activity. The enhancement of working skills, living and life skills consisted of 4 groups of activities, development activities, reducing learning time, increasing learning time for students at basic education level according to government policy.

In accordance with Sukanya Phuphuekok, it was found that the teaching and learning management is linked to the natural community and environment. Practice thinking, practicing, self-assessment and self-improvement, encouraging students to learn happily and successfully, and standard 6 organizes teaching and learning by cultivating morals, ethics and good traits and practicing them into habits.[8]

3. Create a series of activities to reduce learning time to increase the learning time of primary school students as follows: 1. The results of the study of the leadership condition according to the situation of the administrators of the Phra Pariyatidhamma School .The research results are found that by Leadership conditions according to the situation of the administrators of the Phrapariyattidhamma School, the overall management opinion on the situation leadership is at a high level.There are relationships in the organization and power of leaders as follows:

1) The aspect of change, arranged from more to less in three level namely, understanding in education administration, and keeping pace with the current situation, influence on the change in attitude of evaluation and stimulate awareness of the school's mission and vision and the least opinion is to motivate the co-workers to look beyond their interests to the benefit of the school, and the results of the interview have revealed that the changing situation-led leadership is that the management must have vision. The vision of changing old thinking strategies that contradict the school's goals. Change one's mind, and own behavior, change your thinking from thinking to management. Daily work is transformed into thinking through step-by-step planning. Dare to change the organization in which they are responsible towards a better goal. Having your own standpoint and confidence in monks and novices.

2) The aspect of creative, arranged from more to less in three level namely, , including learning team, hopeful thinking and working together to solve problems in the school decentralize decision making for people in the organization and pay attention giving importance to people and work processes and the one that has the least opinion is close attention appearing on the job and in close contact with the students in their school, and according to interviews, leaders should be thought of as a process of thinking, systematic, and not nonsense. The idea of this leader can be put into action and continuously evaluated the practice being creative, solving problems, solving situations in school. It relies on long-term practice, learning experience, problems and solutions with a positive attitude that every problem has a solution.

3) The aspect of relationship within the organization, arranged from more to less in three levels namely, honor and honor to others, increase work potential, good emotional control, stable and sincere to work even in times of crisis and make friendship and concern both outside and in the work time and the one with the least opinions is aimed at building confidence provided continuous personnel and build a good working relationship. According to the interview results, it is found that the executives have to know how to control their emotions. Dare to let others express their opinions, give equal importance to everyone in the school, promote morale and morale in performance, follow the principle of Sangkhahawat 4, having techniques by acting as a good example must be someone who approaches others, have an empathy willing to sacrifice their own interests for their common interests, have good hospitality ,have mercy on each other in order to gain recognition, count, hold trust and be able to work together with happiness, and follow the principle of Brahmavihara.

4) The aspect of power of leaders, arranged from more to less in three levels namely, behavior as a model to the follower, doing the right thing Virtuous Share responsibility for the risks with the followers and makes the followers to believe, respect and trust, trying to imitate the leader and the least comment, having the power to command the followers to be strong, honest and devoted, and the interview results indicated that leaders should exercise their power in the right place. Indeed, it is trusted by subordinates to respect, admire, respect for the leader. These faiths stem from the formation of their own leaders, such as their versatility, honesty generosity to the people in the organization making them have the power to command, the creation of love and faith for the followers. The power of the leader comes from the duty of rewarding, punishment, having knowledge and ability and being respected by the followers. To sit in a person's mind is better than on a person's head, that is the leader who has the power to rule.

2. Development of leadership according to the Buddhist situation of the administrators of the Phrapariyatidhamma School, Sanamluang Division consists of situations of leadership 4 traits: 1) changes, 2) creativity, 3) relationships in the organization, 4) leadership power and 4 situationbased leadership development activities as follows,

1) The changing aspect is creating prestige or ideological influence, inspirational consideration of individuality or individual focus Intellectual stimulation to realize the mission and vision, rewarding according to circumstances talent understanding educational administration to keep up with the current situation, having visions, changing strategies, old ideas that conflict with the goals of the school and dare to change the organization in which they are responsible towards a better goal.

2) Creativity aspect is team learning. There should be a teacher view as a leader. Performance relationships should be based on trust. Leaders should modify their views. Leaders should pay attention and value people. Leaders should emphasize the importance of their customers. They should buried network to achieve two-way communication. Creative leadership requires close attention. Creative 
leadership will decentralize decision making. Creative leaders must have a strong ability to perform missions in the world. Thinking is a process of thinking that is a systematic way to solve problems, solve bad situations in school, keep practicing and creating experiences, learning problems and solutions of the problem.

3) Relationship within the organization aspect is to understand oneself, the one should have an understanding of others, an understanding of the interactions or communication between oneself and others, honoring others, to increase work potential, make friendship and concern both outside and during work time.

4) The power aspect of leaders is how leaders behave as an example to the followers, make followers believe, respect and trust and try to imitate the conduct of the leader. Trust the leader that doing what is right and good virtuous, share responsibility for the risks with the followers ,Leaders avoid using their power for personal gain, but will behave in order to benefit others is a special characteristic of a person or it is the power of the leader that has a profound effect on the followers. The ability to have the power to command strong honesty and selflessness. Influence on followers able to cultivate a sense of value, respect, appreciation, vision and understanding of mission goals for followers.

There are Buddhist principles in promoting 4 Sangkhahawatthu, namely — Dàna: (giving or share things), kindly speech (Piyavàcà ), good doing (Atthacariyà:), participation and behaving oneself properly in all circumstances (Samànattatà) for development of organization, it is a necessary to rely on the Sangha, the Administrator, and the learner develop potential in a society of change.

5) The situation leadership development 4 activities: 1) Transformational Leadership Development Activities 5 Q. 2) Creative Leadership Development Activities "5 Questions to Think About" 3) Relationship Development Activities in Organization "self-management, people management and administration" 4) power development activities of leaders "empowerment"

3.Propose the leadership development according to the Buddhist situation of the administrators of the Phrapariyatidhamma School, Sanamluang Division has been developed it consisted of situations of leadership in 4 traits: 1) Changes, 2) Creativity, 3) Relationships in the organization, 4) Leadership power and situation-based leadership development of 4 activities as follows.

1. The changing aspect is creating prestige or having an ideological influence, inspirational consideration of individuality or individual focus intellectual stimulation to realize the mission and vision.

2. Creativity aspect is team learning. There should be a teacher view as a leader. Performance of relationships should be based on trust. Leaders should modify their views. Leaders should pay attention and value people. Leaders should emphasize the importance of their customers.

3. Relationship within the organization aspect is to understand oneself, by understanding others, understanding of the interactions or communication between oneself and others, and honoring others .Situation Leadership Development in 4 Activities: 1) Transformational leadership development activities with 5 Q. 2) Creative Leadership Development Activities "5-question-thinking activities" 3)
Relationship development activities in Organization "selfmanagement, people management and administration" 4) power development activities of leaders "Power" as shown in figure 1

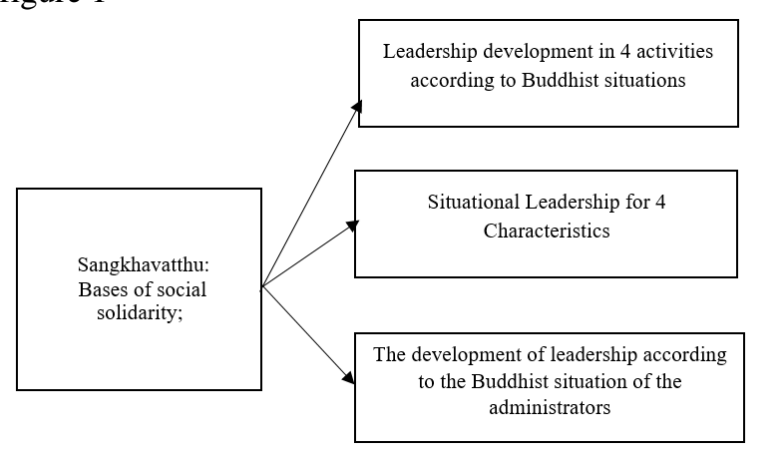

\section{Discussion}

1. The results of the study of the leadership condition according to the situation of the administrators of the Phra Pariyatidhamma School are found that Leadership conditions according to the situation of the administrators of the Phrapariyattidhamma School in all four areas of the Sangha Administrative Area, the overall management opinion on the situation leadership is at a high level, namely creativity, changing, the relationship between the organization and the power of the leader.

1) The aspect of change, arranged from less to more in 3 levels namely, understanding, education administration, and keeping pace with the current situation. Influence on the change in attitude of the temple management organization and stimulate awareness of the school's mission and vision and the least opinion is to motivate the co-workers to look beyond their interests to the benefit of the school, and the results of the interview have revealed that the changing situation-led leadership is that the management must have vision. The vision of changing old thinking, strategies that contradict the school's goals. Change one's mind with own behavior, change your thinking from thinking to management. Daily work is transformed into thinking through step-by-step planning. And dare to change the organization in which they are responsible towards a better goal ,have your own standpoint, have confidence towards monks and novices.

2) The aspect of creative, arranged from less to more in 3 levels namely, learning team, hopeful thinking and working together to solve problems in the school decentralize decision making for people in the organization and pay attention, give importance to people and work processes and the one that has the least opinion is of close attention appearing on the job and in close contact with the students in their school, and according to interviews, leaders should be thought of as a process of thinking, systematic, and not nonsense. The idea of this leader can be put into action and continuously evaluate the practice being creative, solving problems, solving situations in school. It relies on long-term practice, learning experience, problems and solutions by a positive attitude that every problem has a solution.

3) The aspect of relationship with in the organization is arranged from less to more in 3 levels namely, honor and honor others. To increase work potential, good emotional 
control, stable and sincere to work even in times of crisis and make friendship and concern, both outside and in the work time and the one with the least opinions is aimed at building confidence, provided continuous personnel and build a good working relationship. According to the interview results, it is found that the executives have to know how to control their emotions. Dare to let others express their opinions, give equal importance to everyone in the school promote morale and morale in performance, follow the principle of Sangkhavatthu 4, have techniques by acting as a good example must be someone who approaches others, having an empathy willing to sacrifice their own interests for their common interests, having good hospitality, having mercy on each other. In order to gain recognition, count, hold trust and be able to work together with happiness, by following the principle of Brahmavihara.

4) The aspect of power of leaders is arranged from less to more in 3 level namely, including behavior as a model to the followers, doing the right thing Virtuous, share responsibility for the risks with the followers and makes the followers believe, respect and trust, try to imitate the leader and the least commented, that is the power of leader to command the followers to be strong, honest and devoted, and the Interview Results indicate that leaders should exercise their power in the right place. Indeed, it is trusled by subordinates to respect, admire, respect for the leader. These faiths stem from the formation of their own leaders, such as their versatility, honesty generosity towards the people in the organization that is the indicate that leader has the power to command the creation of love and faith for the followers. The power of the leader comes from the duty of rewarding, punishment, having knowledge and ability and being respected by the followers, and create faith for the team in the organization as well. [4]

The results of this research indicate that the administrators of the Phra Pariyatidhamma School have the same opinion in the same direction that situation leadership must change creative relationship in the organization, and leadership power that gives executives a respectable leadership. It is able to manage the Buddhist Dhamma School for efficiency and progress in accordance with the research of Phrakrukhemapiwutapichato (Anchurit) who has researched that "Development of Buddhist participatory administration for the administrators of the Buddhist Dhamma School in Sanamluang Division. The results of the research indicated that the administrative environment of the administrators of the Phra Pariyattidhamma School has found that the administration of the school, led by the abbot of each school, who has the highest power, in addition, the school has authorized the headmaster and teachers. It is the fatherto-child management system. To participate in decision making in organizing or improving the resource management system, decisions making on how to use limited resources to benefit the public and co-organizing or improving in the development management system for efficiency and effectiveness. To join in the implementation of the plan Projects and activities to achieve the goals. There is an evaluation that the actions taken in accordance with the policy of Mae Kong (Dham Sanamluang Director of Dhamma Division) of delegating the power to the abbot of each temple to proceed in the order rule government with a network to support the administration of the school. [5]
Development of participatory administration of the administrators of the Phrapariyattidhamma School consists of a process of participation in 5 areas: 1) awareness participation, thinking, study and research identify problems and causes 2) Participation in policy planning or project plans or activities 3) Participation in decision making in organizing or improving effective resource management system 4) Participation in control and monitoring and evaluate the performance and use the results to benefit. 5) Participation in benefiting from development. The results of the evaluation of participatory management from the sample indicated that the mean accuracy is at the highest level and usefulness, suitability and possibility .The average is at a high level, respectively. The guidelines for development of participatory administration of the administrators of the Phrapariyattidhamma School in the Sangha Administration Area, consists of 6 parts as follows:

1) Principles of 5 participation 2) 6 types of participation 3) 26 stages or forms of engagement 4) 10 aspects of engagement 5) processes of participation 5 participatory activities and 6) 5 activities for the development of participatory management by integrating the principle of influence with Idtibaht 4 (4 fold way of success) to the success of the development of participatory management. For the administration of the Buddhist Dharma School with participation, thought, co-operation, responsibility [6]

2. Development of leadership according to the Buddhist situation of the administrators of the Phra Pariyattidhamma School in the Sangha Administration Region 14, it consists of four situations of leadership traits: 1) changes, 2) creativity, 3) relationships in the organization, 4) leadership power and four situation-based leadership development activities as follows.

1. The changing aspect is creating prestige or having an ideological influence. Inspirational consideration of individuality or individual focus intellectual stimulation to realize the mission and vision. Rewarding according to circumstances talent, understanding educational administration to keep up with the current situation, Having visions, changing strategies, old ideas that conflict with the goals of the school. Dare to change the organization in which they are responsible towards a better goal.

2. The aspect of creativity is team learning. There should be a teacher view as a leader. Performance relationships should be based on trust. Leaders should modify their views. Leaders should pay attention and value people. Leaders should emphasize the importance of their customers. They should build network to achieve two-way communication. Creative leadership requires close attention. Creative leadership will decentralize decision making. Creative leaders must have a strong ability to perform missions in the world thinking is a systematic thought process, solving problems, solving dire situations in school, creating experience, learning problems and solutions of the problems.

3.The aspect of relationship within the organization is to understand oneself, by understanding others, understanding of the interactions or communication between oneself and others ,honoring others. To increase work potential, make friendship and concern both outside and during work time, follow the principles of Sangkhahavatthu 4, having techniques by acting as a good example, being someone 
who approaches others, having an empathy, good hospitality, compassion to each other, following the principle of Brahmaviharn

4. The power of a leader is that leaders behave as an example to the followers, make followers believe, respect and trust and try to imitate the conduct of the leader. Trust the leader by doing what is right and good virtuous, share responsibility for the risks with the followers, leaders avoid using their power for personal gain, but will behave in order to benefit others, it is a special characteristic of a person or it is the power of a leader that has a profound effect on the followers, the ability to have the power to command strong honesty and selflessness,

5. Situational Leadership Development in 4 Activities: 1) Transformational Leadership development activities with 5 Q 2) Creative Leadership Development Activities "5question-to-think activities" 3) Relationship development activities in Organization "self-management, people management and administration" 4) power development activities of leaders "Power", from which it becomes characteristics of leadership, situational leadership. The results of the study have found that [5] 1. Competencies of the administrators of the Phrapariyatidhamma, School overall, is at a high level. When considering the details, it was found that executive competencies are at a high level in every dimension. The top five categories with a high average are self-responsibility and others. [7] [9]

2. Composition of competencies of administrators of religious studies in Sanamluang Division according to Buddhist principles, it consists of 5 elements which are 1) organizational management competencies component, 2) promotion performance and human resource development component, 3) leadership personality competencies component, 4) self-efficacy in accordance with the Buddhist concept component, 5) knowledge competencies in Buddhist administration, the five elements are important factors for the development of the Buddhist religious studies institute.

3. The evaluation of the competency model of the administrators of the Phrapariyattidhamma School according to Buddhist principles has found that it is appropriate, useful, coherent, and the possibility is in the same direction that will lead to the development of the competency of the administrators of the PhrapariyattiDhamma School, Pali division [8]

1. Propose the leadership development according to the Buddhist situation of the administrators of the Phra Pariyatidhamma School in the Sangha. As follows,

1. The changing aspect is creating prestige or having an ideological influence. inspirational consideration of individuality or individual focus Intellectual stimulation to realize the mission and vision.

2. The creativity aspect is team learning. There should be a teacher view as a leader. Performance relationships should be based on trust. Leaders should modify their views. Leaders should pay attention and value people. Leaders should emphasize the importance of their customers.

3. The aspect of relationship within the organization is to understand oneself, by understanding others, understanding the interactions or communication between oneself and others honoring others, to increase work potential making friendship and concern both outside and during work time.
4. The aspect of power of a leader is that leaders behave as an example to the follower, make followers believe, respect and trust and try to imitate the conduct of the leader trust the leader that doing what is right and good virtuous, and share responsibility for the risks with the followers.

The results of this research are consistent with the research of Hartley, J. and B. Hinksman has made research on Leadership Development: A Systematic Review Research is based on publications, research on leadership development. Research has found that leadership development is related to the development of the individual's ability to help them learn by new methods. The best leadership development should focus on strategy, and the context of the organization in order to design and put into practice properly, Leadership development can be done in two ways: 1) a formal manner, such as training courses development program and 2) informal aspects that support leadership development, such as practical experience in section of the need for leadership development. The conceptual competence framework should be used to identify the leadership that is required in each organization. To be used as a criterion for determining core skills and as a guideline for developing the lack of competencies of each employee. In addition, assessments such as 360-degree assessments should also be used in conjunction with the competency conceptual framework. A popular approach used in leadership development includes a 360-degree assessment, mentoring, teaching, networking. Learning from practice being assigned a challenging task temporarily, learning from other agencies ,successor planning formal training development of high-achieving civil servants organization development and working together as partners that is the model of leadership used in leadership development. [10]

\section{Conclusion}

Leadership development according to the Buddhist situation of the administrators of the Prapariyattidhamdhamma Division school in the Sangha Administration Region 14, consists of characteristics of situational Leadership in 4 aspects, namely, 1) Change 2) Creativity 3) Relationships in the organization 4) leadership power by Integration with Buddhist principles in the promotion, namely giving( Dàna ), kindly speech (Piyavàcà), useful conduct (Atthacariyà), participation and behaving oneself properly in all circumstances (Samànattatà) and the leadership development activities according to the situation of 4 activities: 1) Leadership development activities with 5 Q 2) Creative leadership development activities "5 questions to think about" 3. Activities for relationship development in the organization "self management, people management and management". 4. Leadership Power Development Activity "Power of Power

\section{References}

[1] Phra Krisakorn Akkharaphopmethee, "A Study of Transformational Leadership of Primary School Administrators Under Bangkok, Klong Toey District", Master's 
Thesis, Faculty of Education: Chulalongkornrajavidyalaya University, 2014.

[2] Praong Rasamekaew, Political Science. Social Sciences, Phra Nakhon: Mongkol Publication, 2002.

[3] Kamon Phuprasert, Academic administration in educational institutions, (Bangkok: Kor Phon Limited Company, 2001), page 33.

[4] Prakramkaew, Political Science, Social Sciences, (Phra Nakhon: Mongkol Publication, 2002),

[5] Phra Kru Khemapiwut Apichato (Anchurit), "Development of Buddhist participatory administration for the administrators of the Buddhist Dhamma School of Dharma", Ph.D. Buddhist Education Administration Program, (Graduate School: Mahachulalong kornrajavidyalaya University, 2018)

[6] Phra Kru Sangkharak Weerasak Chanthawaso (Cars Chanwong), "The Buddhist Change Leadership Model of Elementary School Administrators, Thonburi District, Bangkok", Doctor of Philosophy Ph.D. Buddhist Education Administration Program, Graduate School: Mahachulalongkornrajavidyalaya University, 2016.

[7] PhraKru Kittiyanavisit (Thanakittiyano / Homol), "Competency of the administrators of the Buddhist Religious Studies Center, Dharma Department: Buddhism Principles", Doctor of Philosophy Buddhist Education Administration Program, (Graduate School: Mahachulalongkornrajavidyalaya University, 2014), Abstract.

[8] Samut Chamnan, "The Development of School Management Model Based on School", Doctor of Education Thesis, Graduate School: Burapha University, 2003.

[9] Hartley, J. and B. Hinksman), "Leadership development : A systematic review of the literature", Warwickshire: Warwick Business School, 2003. 